\title{
Diversity of Harmful and Beneficial Insect Fauna in Pigeonpea [Cajanus cajan (L.)] Ecosystem in Tamil Nadu, India
}

\author{
J. Alfred Daniel", N. Chitra and M. Mathialagan \\ Department of Agricultural Entomology, Tamil Nadu Agricultural University, \\ Coimbatore-3, Tamil Nadu, India \\ *Corresponding author
}

\section{A B S T R A C T}

\begin{tabular}{|l|}
\hline Ke y w o r d s \\
Pigeonpea \\
{$[$ Cajanus cajan $(\mathrm{L})]$,} \\
Ecosystem, Diversity \\
\hline Article Info \\
\hline Accepted: \\
04 July 2018 \\
Available Online: \\
10 August 2018 \\
\hline
\end{tabular}

The study of biodiversity associated with agro ecosystem is of significance for agro ecologist and conservation biologist, since the maintenance of biological diversity is essential for productive and ecologically sustainable agriculture. Field experiment was conducted to inventorize the insect fauna in pigeon pea ecosystem from February 2015 to July 2015. A total of 77 different species of insects belonging to 45 families under 10 orders were collected. Of the 77 species recorded, 53 species were harmful and 24 were beneficial. The Simpson's index of Diversity was the highest for beneficial insects (0.94) and for harmful insects it was (0.93). Similar trend was observed in Shannon-Wiener index also for beneficial and harmful insects with values of 3.12 and 3.00 , respectively. The values of Margalef index for the beneficial and harmful insects revealed that maximum richness (6.35) was accounted for harmful insects followed by beneficial insects (5.32). The species evenness was maximum for beneficial insects $(0.55)$, whereas for the harmful insects it was (0.45).

\section{Introduction}

Pigeon pea (Cajanus cajan (L.) Mill Sp.) is one of the most important and widely cultivated pulse crop in India. Pest menace on Pigeon pea has assumed serious proportions, even to the extent of suicidal deaths of farmers. It is attacked by a large number of insects at all stages of growth i.e., seedling to harvest stage and as per a conservative estimate, losses due to these insect pests may vary from $27 \%$ to even $100 \%$. Among the various constraints for low productivity in pigeon pea crop, the infestation of insect pests is the main contributor. There are several reports indicating that pigeon pea is attacked by different insect pests from different parts of the country and other countries, as well (Singh and Singh, 1991; Rao et al., 2002; Akhilesh and Parasnath, 2003). Information on pest complex in particular agro climatic condition is a prerequisite, which helps in designing a successful pest management strategy. Information pertaining to diversity and seasonal occurrence of pests on this crop is of significance in effective pest management practices. Arthropods are important components of ecosystems occupying vital positions in food webs, dynamics of populations and communities. They play 
various roles in ecosystems acting as herbivores, predators, decomposers, parasitoids and pollinators. Population ecologists discussed diversity of arthropods in two aspects, species richness i.e., the number of species in a set of sample and equitability e.g., the number of individuals of each species in a sample (Disney, 1999). There are evidences that species rich ecosystems are more stable than species-poor ecosystems. It is now established that arthropod predators suppress the pest populations (Chang and Kareiva, 1999 and Synmondson et al., 2002). In view of scant information on diversity of insects on pigeon pea ecosystem the present study was undertaken.

\section{Materials and Methods}

\section{Experimental site}

Field experiment was conducted in $30 \mathrm{X} 40$ $\mathrm{m} 2$ plots to inventorize the insect fauna in pigeon pea ecosystem from February 2015 to July 2015 at New area of Tamil Nadu Agricultural University. The variety Co $(\mathrm{Rg}) 7$ was cultivated. The agronomic practices were carried out as per the crop production guide of the University, Coimbatore. Insect fauna was collected using different methods of collection viz., active searching and net sweeping.

\section{Active searching}

It was done in the early morning or evening hours. The site was searched for a total of two hours per week. The population of sucking pests was visually recorded.

\section{Net sweeping}

It is very effective for the collection of flying and jumping insects. Sweeping of vegetation was as random as possible from ground level to the height of the crop. The nets used in systematic sweeping of the ground level were made of thick cotton cloth with a diameter of $30 \mathrm{~cm}$ at the mouth and a bag length of $60 \mathrm{~cm}$.

\section{Identification of arthropods}

The collected arthropods were sorted out based on taxon. Soft bodied insects were preserved in 70 per cent ethyl alcohol in glass vials. Other arthropods were card mounted or pinned. The preserved specimens were photographed and identified based on the taxonomic characters. All arthropod species were identified to the lowest possible taxon. Insects were identified by comparing with the specimens in the Department of Agricultural Entomology, Tamil Nadu Agricultural University.

\section{Measurement of diversity}

Relative density of the species was calculated by the formula, Relative Density (\%) = (Number of individuals of one species / Number of individuals of all species) X 100. Species or alpha diversity of the sites was quantified using Simpson's diversity Index (SDI), (Simpson, 1949) and Shannon-Wiener index (Shannon, 1949). SDI is a measure of diversity which takes into account the number of species present, as well as the relative abundance of each species. SDI is calculated using the formula, $\mathrm{D}=\Sigma n(n-1) / N(N-1)$ where $n=$ total number of organisms of a particular species and $N=$ total number of organisms of all species. Subtracting the value of Simpson's index from 1, gives Simpson's Index of Diversity (SID). The value of the index ranges from 0 to 1 , the greater the value the greater the sample diversity. ShannonWiener index $\left(H^{\prime}\right)$ is another diversity index and is given as follows: $H^{\prime}=-\Sigma P i \ln (P i)$, where $P i=S / N ; S=$ number of individuals of one species, $N=$ total number of all individuals in the sample, $l n=$ logarithm to base e. The higher the value of $H^{\prime}$, the higher the diversity. 
Table.1 Inventory of insects in pigeonpea ecosystem

\begin{tabular}{|c|c|c|}
\hline S. No. & Insect (Order: Family: Scientific Name) & Role \\
\hline 1. & Odonata: Libullelidae: Crocothemis servillia & Beneficial \\
\hline 2. & Odonata: Libullelidae: Pantala falvescens & Beneficial \\
\hline 3. & Dictyoptera: Mantidae: Mantis religiosa & Beneficial \\
\hline 4. & Isoptera: Termitidae:Odontotermes sp. & Harmful \\
\hline 5. & Orthoptera: Acrididae: Acrida exaltata & Harmful \\
\hline 6. & Orthoptera: Acrididae: Neothacris simulans & Harmful \\
\hline 7. & Hemiptera: Aleyrodidae: Bemisia tabaci & Harmful \\
\hline 8. & Hemiptera: Alydidae: Leptocoris oratorius & Harmful \\
\hline 9. & Hemiptera: Coreidae: Anoplecnemis phasiana & Harmful \\
\hline 10. & Hemiptera: Coreidae: Clavigrella gibbosa & Harmful \\
\hline 11. & Hemiptera: Coreidae: Clavigrella horrens & Harmful \\
\hline 12. & Hemiptera: Coreidae: Cletus punctiger & Harmful \\
\hline 13. & Hemiptera: Coreidae: Riptortus pedestris & Harmful \\
\hline 14. & Hemiptera: Cicadellidae: Empoasca kerri & Harmful \\
\hline 15. & Hemiptera: Coccidae: Ceroplastes cajani & Harmful \\
\hline 16. & Hemiptera: Eurybrachidae: Eurybrachis tomentosus & Harmful \\
\hline 17. & Hemiptera: Pentatomidae: Coptosoma cribrarium & Harmful \\
\hline 18. & Hemiptera: Pentatomidae: Dolycoris indiucs & Harmful \\
\hline 19. & Hemiptera: Pentatomidae: Nezara virudula & Harmful \\
\hline 20. & Hemiptera: Pyrrhocoreidae: Dysdercus sp. & Harmful \\
\hline 21. & Hemiptera: Pseudococcidae: Ferrisia virigata & Harmful \\
\hline 22. & Hemiptera: Reduviidae: Rhnocoris sp. & Beneficial \\
\hline 23. & Diptera: Agromyzidae: Melanoagromyza obtusa & Harmful \\
\hline 24. & Coleoptera: Bruchidae: Callosobruchis analis & Harmful \\
\hline 25. & Coleoptera: Bruchidae: Callosobruchis chinensis & Harmful \\
\hline 26. & Coleoptera: Bruchidae: Callosobruchis maculatus & Harmful \\
\hline 27. & Coleoptera: Buprestidae: Sphenoptera sp. & Harmful \\
\hline 28. & Coleoptera: Carabidae: Ophionea nigrofasciata & Beneficial \\
\hline 29. & Coleoptera: Cassididae: Cassida circumdata & Harmful \\
\hline 30. & Coleoptera: Cetonidae: Oxycetonia albopunctata & Harmful \\
\hline 31. & Coleoptera: Cetonidae: Oxycetonia versicolor & Harmful \\
\hline 32. & Coleoptera: Chrysomelidae: Aulocophora foveicollis & Harmful \\
\hline 33. & Coleoptera: Coccinellidae: Coccinella transversalis & Beneficial \\
\hline 34. & Coleoptera: Coccinellidae: Epilachna vigintioctopunctata & Beneficial \\
\hline 35. & Coleoptera: Coccinellidae: Harmonia octomaculata & Beneficial \\
\hline 36. & Coleoptera: Coccinellidae: Menochilus sexmaculatus & Beneficial \\
\hline 37. & Coleoptera: Coccinellidae: Micraspis discolor & Beneficial \\
\hline
\end{tabular}




\begin{tabular}{|c|c|c|}
\hline 38. & Coleoptera: Meloidea: Hycleus pustulatus & Harmful \\
\hline 39. & Coleoptera: Meloidea: Hycleus orientalis & Harmful \\
\hline 40. & Coleoptera: Meloidea: Hycleus phalerata & Harmful \\
\hline 41. & Coleoptera: Meloidea: Hycleus thunbergii & Harmful \\
\hline 42. & Coleoptera: Curculionidae: Alicidodes collaris & Harmful \\
\hline 43. & Coleoptera: Curculionidae: Myllocerus viridanus & Harmful \\
\hline 44. & Coleoptera: Staphylinidae: Paederus fuscipes & Harmful \\
\hline 45. & Neuroptera: Chrysopidae: Chrysopa sp. & Beneficial \\
\hline 46. & Hymenoptera: Apidae: Apis cerana indica & Beneficial \\
\hline 47. & Hymenoptera: Apidae: Apis dorsata & Beneficial \\
\hline 48. & Hymenoptera: Apidae: Apis florea & Beneficial \\
\hline 49. & Hymenoptera: Braconidae: Myosoma chinensis. & Beneficial \\
\hline 50. & Hymenoptera: Chalcididae: Brachymeriasp. & Beneficial \\
\hline 51. & Hymenoptera: Eurytomidae: Eurytoma sp. & Beneficial \\
\hline 52. & Hymenoptera: Formicidae: Componotus sp. & Beneficial \\
\hline 53. & Hymenoptera: Megachilidae: Megachile sp. & Harmful \\
\hline 54. & Hymenoptera: Vespidae: Sceliphron sp. & Beneficial \\
\hline 55. & Hymenoptera: Ichneumonidae: Charops sp. & Beneficial \\
\hline 56. & Hymenoptera: Ichneumonidae: Isotima sp. & Beneficial \\
\hline 57. & Hymenoptera: Ichneumonidae: Trathala sp. & Beneficial \\
\hline 58. & Hymenoptera: Ichneumonidae: Xanthopimpla sp. & Beneficial \\
\hline 59. & Hymenoptera: Torymidae: Podagrion sp. & Beneficial \\
\hline 60. & Lepidoptera: Erebidae: Amsacta albistriga & Harmful \\
\hline 61. & Lepidoptera: Erebidae: Olepa ricini & Harmful \\
\hline 62. & Lepidoptera: Erebidae: Euproctis fraterna & Harmful \\
\hline 63. & Lepidoptera: Gelechiidae: Aproarema modicella & Harmful \\
\hline 64. & Lepidoptera: Noctuidae: Helicoverpa armigera & Harmful \\
\hline 65. & Lepidoptera: Noctuidae: Plusia sp. & Harmful \\
\hline 66. & Lepidoptera: Noctudidae: Spodoptera litura & Harmful \\
\hline 67. & Lepidoptera: Papilionidae: Papilio polytes & Harmful \\
\hline 68. & Lepidoptera: Pieridae: Eurema hecabe & Harmful \\
\hline 69. & Lepidoptera: Lycaenidae: Euchrysops cnejus & Harmful \\
\hline 70. & Lepidoptera: Lycaenidae: Lampides boeticus & Harmful \\
\hline 71. & Lepidoptera: Notodontidae: Neostaurpus alternus & Harmful \\
\hline 72. & Lepidoptera: Pterophoridae: Exelastis atomosa & Harmful \\
\hline 73. & Lepidoptera: Pterophoridae: Sphenarches sp. & Harmful \\
\hline 74. & Lepidoptera: Crambidae: Etiella zinckinella & Harmful \\
\hline 75. & Lepidoptera: Crambidae: Maruca vitrata & Harmful \\
\hline 76. & Lepidoptera: Sphingidae: Acherontia styx & Harmful \\
\hline 77. & Lepidoptera: Sphingidae: Cephanodes sp. & Harmful \\
\hline
\end{tabular}


Species richness was calculated for the three sites using the Margalef index (Margalef, 1958) which is given as Margalef Index, $\alpha=(S$ - 1)/ln(N); $S=$ total number of species, $N=$ total number of individuals in the sample. Species evenness was calculated using the Pielou's Evenness Index (E1) (Pielou, 1966) Pielou's Evenness Index, $E 1=H^{\prime} / \ln (S) ; H^{\prime}=$ ShannonWiener diversity index, $S=$ total number of species in the sample. As species richness and evenness increase, diversity also increases (Magurran, 1988). Beta diversity is a measure of how different (or similar) ranges of habitats are in terms of the variety of species found in them (Magurran, 1988).

\section{Results and Discussion}

77 different species of insects belonging to 45 families under 10 orders were collected. Of the 77 species recorded, 53 species were harmful and 24 were beneficial. An inventory of insects that were collected from the pigeon pea ecosystem is enlisted in Table 1. It was found that the harmful insects $(68.83 \%)$ were abundant than beneficial insects (31.16\%). The Simpson's index of Diversity was the highest for beneficial insects (0.94) and for harmful insects it was (0.93). Similar trend was observed in Shannon-Wiener index also for beneficial and harmful insects with values of 3.12 and 3.00, respectively. The values of Margalef index for the beneficial and harmful insects revealed that maximum richness (6.35) was accounted for harmful insects followed by beneficial insects (5.32). The species evenness was maximum for beneficial insects $(0.55)$, whereas for the harmful insects it was $(0.45)$. From the present study it was found that Coleoptera is the most diverse insect order in pigeon pea ecosystem followed by Lepidoptera.

Globally 349 species of insects have been observed feeding on pigeon pea of which 191 species have been reported from India (Lateef and Reed, 1990). The most serious pests are those that attack the reproductive structures including buds, flowers and pods (Shanower et al., 1999). The field infestation of bruchids Callosobruchus spp. was observed in the present study. Earlier field infestation of $C$. chinensis and $C$. maculatus was reported in pigeon pea (Shiv, 1987) and per cent infestation of pulse beetle on pigeon pea varieties varied from 1.2 to 10.2 per cent with a mean of 5.15 per cent on pod basis and percentage seed infestation on seed basis from 0.4 to 4.8 (Bindra and Jokhmola, 1967). Several natural enemies were recorded in the present study.

More than 60 species of arthropods were recorded as predators of Helicoverpa armigera in India (Romeis and Shanower, 1996). The predators and parasitods have been summarized for the key insects pest in pigeonpea such as Helicoverpa armigera (Sithanantham et al., 2005), Maruca vitrata (Sharma et al., 1998), Melanoagromy zaobtusa (Shanower et al., 1998). Around 97 species of parasitods have been recorded on different insect pest occurring in pigeon pea (Rabindra et al., 2004). The disappearance of eggs of $H$. armigera (Romeis and Shanower, 1996) and Maruca vitrata had been suggested due to predators. Paucity of information on the key natural enemies and their impact under field conditions need to be addressed with a view to provide basis for selecting candidate for augmentation and conservation (Sithanantham et al., 2005).

This study increased the information and knowledge available on the biodiversity of insects in pigeon pea ecosystem. This information will be help in future for species specific work and for launching conservation strategies and pest management programmes in pigeon pea ecosystem.

\section{References}


Akhilesh, K. and Parasnath, 2003. Pest complex and their population dynamics on an early variety of pigeon UPAS 120 at Varanasi. Ind. J. Ent. 65(4): 453460.

Bindra, O.S. and Jokhmola, S.S. 1967. Incidence and losses caused by pod infesting insects in different varieties of pigeonpea, Cajanus cajan (L.) Millsp. J. Agrl. Sci., 37: 177-186.

Chang, G. C. and Kareiva, P. 1999. The case for indigenous generalists in biological control. In: Theoretical approaches to biological control, (Eds.) Hawkins, B.A. and H.V. Cornell. Cambridge University Press, Cambridge, United Kingdom. pp. 103-115

Chitra, N and Soundararajan, R.P. 2011. Insect Diversity in Pigeonpea Ecosystem in Tamil Nadu. I. J.Ent., 73(4), 349-356.

Disney, R. H. L. 1999. Insect biodiversity and demise of alpha taxonomy. Antenna: Bull. R. Entomol. Soc. 23: 84-88.

Lateef, S.S. and Reed, W. 1990. Insect pests of pigeonpea. In: Insect Pests of Tropical Food Legumes (Singh, S.R. ed.) Chichester, UK: Wiley. 451pp.

Magurran, E.A. Ecological Diversity and its Measurement. Croom Helm, Australia, $1988 ; 215$.

Margalef R. Temporal succession and spatial heterogeneity in phytoplankton In: Perspectives in Marine Biology. University of California Press, Berkeley, 1958; 323-347.

Pielou EC. The measurement of diversity in different types of biological collections. J. Theo. Biol., 1966; 13: 131-144.

Rabindra, R.J., Ballal, C.R. and Ramanaujam. B. 2004. Biological options for insect pests and nematode management in pulses. In: Pulses in new perspective. Kanpur: Indian Society of Pulses
Research and Development, pp. 400475.

Rao, R. G. V., Saxena, K. B., Yang Shiying, P. and Weiguang, T. 2002. Insect pest problems of pigeon pea in Gangni and Hainan province of China. International Chickpea and Pigeon pea, New Letters, p. 48

Romeis, J. and Shanower, T.G. 1996. Arthropod natural enemies of Helicoverpaarmigera (Hubner) (Lepidoptera: Noctuidae) in India. Bio. Sci.Tech., 6: 481-508.

Shannon, C. E. and Wiener, W. 1949. The mathematical theory of communication. University Illinois press. Urbana. pp. 324

Shanower, T.G, Lal, S.S. and Bhagwat, V.R. 1998. Biology and management of Melanagromyzaobtusa (Malloch) (Diptera: Agromyzidae). Crop Prot., 17: 249-263.

Shanower, T.G., Romeis, J. and Minja, E.M. 1999. Insect pests of pigeonpea and their management. Ann. Rev. Ent., 44:77-96

Sharma, H.C.., Saxena, K.B. and Bhagwat, V.R. 1999. The Legume Pod borer, Maruca vitrata: Binomics and Management. Information Bulletin no: 55. Patancheru, Hyderabad: International Crops Research Institute for Semi-Arid Tropics. 36pp.

Shiv, SK. 1987. First record of Callosobruchus spp. infesting pigeonpea, Cajanus cajan (L.) Millsp. Under field conditions in Haryana. Bull Grain Technol., 27: 127-128

Simpson, E. H. 1949. Measurement of diversity. Nature. 163: 688.

Singh, H. K. and Singh, H. N. 1991. Some major pest incidence on certain late cultivars of pigeon pea Cajanus cajan L. during half pod formation stage. Ind. J. Ent. 53(2): 298-303 
Sithananatham, S. Singh, S.P. and Romeis, J. 2005. Biological control of New Delhi: Oxford \& IBH Publishing Helicoverpa: Research status, constraints and opportunities. In: Heliothis/Helicoverpa Management. Emerging Trends and Strategies for Future Research. (Sharma. H.C. ed) Co. Pvt. Ltd. pp: 329-369.

Synmondson, W.O.C., Sunderland, K.D. and Greenstone, M.H. 2002. Can generalist predators be effective biocontrol agents. Ann Rev Entomol., 47: 561-594

\section{How to cite this article:}

Alfred Daniel, J., N. Chitra and Mathialagan, M. 2018. Diversity of Harmful and Beneficial Insect Fauna in Pigeonpea [Cajanus cajan (L.)] Ecosystem in Tamil Nadu, India. Int.J.Curr.Microbiol.App.Sci. 7(08): 396-402. doi: https://doi.org/10.20546/ijcmas.2018.708.045 